Sains Malaysiana 49(7)(2020): 1627-1638

http://dx.doi.org/10.17576/jsm-2020-4907-14

\title{
Spatial Analysis of Food and Waterborne Diseases in Sabah, Malaysia
}

(Analisis Reruang bagi Penyakit Bawaan Makanan dan Air di Sabah, Malaysia)

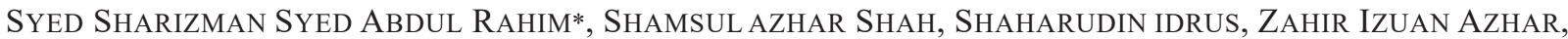 \\ MOHD ROHAIZAT HASSAN \& NAZARUDIN SAFIAN
}

\begin{abstract}
Food and waterborne disease (FWBD) epidemic can produce devastating public health outcomes. From 1990 to 2006 , the annual notifications for FWBDs in Malaysia ranged from 2,000 to about 10,000 cases. The purpose of this study was to describe the spatial epidemiology of FWBDs in four districts of Sabah from the year 2011 to 2014. This study was a retrospective review of four years (i.e. 2011 to 2014) worth of data from Kota Kinabalu, Penampang, Putatan, and Papar districts. All reported cases of cholera, dysentery, food poisoning, typhoid, and viral hepatitis A from these areas and district health offices were included. Coordinates for the locations of the cases were based on home addresses. Among a total of 1997 cases of FWBDs, food poisoning was the highest reported disease with 1787 (89.4\%) cases. Kota Kinabalu had the most reported cases of FWBDs with 1368 (68.5\%). In the year 2012, FWBD incidence was the highest at 16.44 per 10,000 populations. Kernel density estimation demonstrated hot spots of food poisoning and cholera in the western areas near the coast, while typhoid and viral hepatitis $A$ cases had minimal hot spots and appeared to be dispersed. Average nearest neighbour analysis showed clusters of food poisoning and cholera cases. Further analysis with the nearest neighbour hierarchical spatial clustering presented 32 clusters of food poisoning and 7 clusters of cholera. Food poisoning and cholera usually occur in clusters. From these findings, it can be concluded that these areas, food poisoning, and cholera have significant spatial clustering and patterns. Meanwhile, other FWBDs did not occur in clusters for this study. This indicates the possibility of under-reporting or real dispersion of cases brought about by an efficient mechanism of spread from a common source.
\end{abstract}

Keywords: Cluster; foodborne; GIS; spatial analysis; waterborne

\section{ABSTRAK}

Epidemik penyakit bawaan makanan dan air (FWBD) boleh mengakibatkan masalah kesihatan awam. Dari tahun 1990 hingga 2006, dilaporkan bahawa bilangan kes tahunannya berada dalam lingkungan 2,000 hingga 10,000 kes. Tujuan kajian ini adalah untuk menghuraikan epidemilogi ruang bagi penyakit bawaan makanan dan air di empat buah daerah di Sabah dari tahun 2011 hingga 2014. Sorotan retrospektif ini melibatkan data selama 4 tahun (2011 hingga 2014) yang dikutip daripada Kota Kinabalu, Penampang, Putatan dan Papar, Sabah. Semua kes kolera, disentri, keracunan makanan, tifoid dan hepatitis A virus yang dilaporkan oleh pejabat kesihatan kawasan dan daerah dikaji. Koordinat bagi lokasi kes adalah berdasarkan alamat rumah. Daripada sejumlah 1,997 kes FWBD, keracunan makanan dilaporkan sebagai kes yang paling tinggi dengan 1,787 (89.4\%) kes. Kota Kinabalu merekodkan bilangan kes yang paling tinggi, iaitu 1,368 (68.5\%). Bilangan kes FWBD adalah paling tinggi pada tahun 2012 dengan catatan 16.44 per 10,000 populasi. Anggaran kepadatan Kernel menunjukkan bahawa kawasan yang mencatatkan kes keracunan makanan dan kolera tertinggi adalah di bahagian barat berhampiran pantai. Kes-kes tifoid dan hepatitis A virus tidak banyak dilaporkan di kebanyakan kawasan dan kelihatan berselerak. Analisis jiran terdekat purata menunjukkan kelompok bagi kes-kes keracunan makanan dan kolera sahaja. Analisis lanjut melalui pengkelompokan ruang hierarki jiran terdekat menunjukkan 32 kelompok bagi kes keracunan makanan dan 7 kelompok bagi kes kolera. Keracunan makanan dan kolera biasanya berlaku secara berkelompok. Keputusan daripada kajian ini menunjukkan kes keracunan makanan dan kolera mempunyai ciri-ciri kelompok dan corak reruang yang signifikan. Sementara itu, penyakit bawaan makanan dan air lain bagi kajian ini tidak berlaku secara berkelompok. Ini mungkin disebabkan terdapat kes yang tidak dilaporkan atau kes berselerak sahih berlaku dan merebak dengan cepat berasal daripada punca yang sama.

Kata kunci: Analisis ruang; bawaan air; bawaan makanan; GIS; kelompok 


\section{INTRODUCTION}

The global number of food and water-borne diseases (FWBD) reported is largely unknown (Newell et al. 2010). The FWBD epidemic can produce devastating health outcomes in both developing and developed countries. In Malaysia, the annual notifications of FWBDs ranged from 2000 to about 10,000 cases from 1990 to 2006 (Ministry of Health 2006).

Environmental factors such as climate, seasonality, temperature, and rainy seasons have shown relationships and can thus manifest temporal variants (Carrel et al. 2009) Malaysia, in general and Sabah specifically is affected by climate change, which is evident in situations that have occurred such as floods, landslides, and tropical storms, which are attributed to the cyclical monsoon seasons. Weather extremes such as storms, floods, and droughts cause the emergence of climate-sensitive diseases from the contamination of water and environment (Alhoot et al. 2016). In Malaysia and in particularly Sabah, the major factor contributing to food and waterborne diseases is insanitary food handling procedures which accounted for more than $50 \%$ of the poisoning episodes (Soon et al. 2011).

Spatial analysis has the potential for monitoring and managing FWBD surveillance. Its examples include interactive mapping, analysing dynamic changes for transmission risk factors, and creating a framework for the disease management system. The current static or pin map of disease distribution can be improved by using dynamic disease mapping, which helps in making decisions, illuminating the causes, and generating hypotheses of the cause of disease. It is achievable via ecological or epidemiological risk assessment. For example, data of spatio-temporal changes and geographical statistical correlation or interpretation can be used together (Abdul Rauf \& Abdul Malek 2012).

This study is conducted in the four districts of Sabah, which are Kota Kinabalu, Penampang, Putatan, and Papar. Sabah is one of the states in Malaysia located in the northernmost part of Borneo, recording a total population of 3,120,040 and an annual population growth rate of $1.7 \%$. Its major ethnic groups are Kadazan/Dusun (17.9\%), Bajau (14.0\%), Chinese (9.1\%), Malay (5.7\%), Murut (3.3\%), other Bumiputera (20.5\%), and noncitizens (27.8\%) (DOSM 2020). The purpose of this study was to describe the spatial epidemiology of FWBDs in these four districts of Sabah from the year 2011 to 2014.

\section{MATERIALS AND METHODS}

This was a retrospective review and spatial analysis spanning over four years (i.e. 2011-2014) of data for FWBDs, which included cholera, dysentery, food poisoning, typhoid, and viral hepatitis A. The analysis included reported cases in the online disease notification system. All the reported cases from the Area and District
Health Offices were taken as samples, whereas the coordinate system used was Rectified Skew Orthomorphic (RSO) Timbalai 1948 Borneo (metres). Approval and registration for this research were obtained from the Sabah State Health Department, Universiti Kebangsaan Malaysia (FF-2014-319), and the National Medical Research Register (NMRR-14-331-19140), Malaysia.

Next, programs such as Statistical Package for the Social Sciences (SPSS) v20, ArcGIS v10, and CrimeStat IV were used for data analysis and mapping. In particular, five environmental features were analysed via a proximity analysis spanning 500 metres, which were the nearest market, sewage plant, municipal landfills, water treatment plant, river, and coastline.

Spatial analysis is a type of geographical analysis which seeks to explain patterns of human behaviour and its spatial expression in terms of mathematics and geometry, that is, locational analysis (Esri 2013). Points and polyline were plotted and analysed accordingly based on the resulting FWBD diagnosis. Meanwhile, kernel function was used to create a smooth map of values from spatial data, which appeared like a spatially-based histogram. It depicted the level at each location along the map reflecting the point pattern intensity for the surrounding area (Anselin et al. 2000). Next, the nearest neighbourhood method was used to calculate the distance to the nearest neighbour. The ratio is called the Nearest Neighbourhood Index. If the ratio is less than 1, the observed distribution is clustered; if the ratio is larger than 1, it is dispersed (Esri 2013). In the nearest neighbour hierarchical spatial clustering, clusters are identified and put together based on two criteria, namely the threshold distance and the minimum number of points that are close enough (Safian et al. 2008).

\section{RESULTS AND DISCUSSION}

A total of 1997 cases of FWBDs were reported from the four districts of Sabah from the year 2011 to 2014. The highest age group was between 10 and 14 years old with $441(10.4 \%)$ cases, while the female group had a slightly higher number of cases with 1094 (54.8\%). The ethnic group of Peribumi Sabah was the representation and presented with $1421(71.2 \%)$ cases. Meanwhile, in terms of diagnosis, food poisoning was the highest reported disease from all four districts with 1787 (89.4\%) cases, whereas dysentery was the least reported with only 2 $(0.1 \%)$ cases (Table 1$)$. In an acute diarrhoea study done locally, it was found that young adults had the highest incidence of acute diarrhoea, which could be attributed to their lifestyle and eating habits as they were likely to be single and more active. The same study also showed that Peribumi Sabah having the highest incidence of acute diarrhoea (Gurpreet et al. 2011). However, under five years of age, Bangladesh had the highest incidence of typhoid (Dewan et al. 2013). Part of the epidemiology 
of foodborne illness is tied to behavioural factors, sociocultural practices, food choices and availability, consumer and societal attitudes towards food, and food preparation practices (Tam 2008).

Kota Kinabalu District, which is the most populated among the four districts, had the highest number of reported cases with 1368 (68.5\%) cases of FWBDs from the year 2011 to 2014 . In contrast, Putatan had the least reported cases with $166(8.3 \%)$. In terms of the year, FWBDs were highest reported in the year 2012 with 622 (31.1\%) cases, while 2011 showed the lowest amount of reported cases with $380(19.0 \%)$ cases. The highest FWBD incidence was in 2012 with 16.44 per 10,000 population.

Table 2 shows the association between the outbreak and sporadic cases of food and waterborne cases in the four districts of Sabah from 2011 to 2014. A significant difference was seen in the outbreak and sporadic cases by district $(\chi 2=233.355, \mathrm{p}<0.01)$, ethnicity $(\chi 2=16.204$, $\mathrm{p}<0.05)$, and age $(\chi 2=249.628, \mathrm{p}<0.01)$. In the findings, food poisoning had the most reported number of cases and clusters. Gastrointestinal infections such as salmonellosis or cryptosporidiosis may show significant spatio-temporal clusters of food poisoning and be transmitted by disease carriers (Pardhan-Ali et al. 2012). Food poisoning may also depict a widespread occurrence in numerous households, especially if the causative food or products are sold at supermarkets and retail outlets (Asao et al. 2003) with 420 cases frequently ingested dairy products manufactured by a factory in Osaka City.

In Figures 1 to 4, the Kernel Density Estimation (KDE) analysis shows the high-density areas of food poisoning and cholera cases from the year 2011 to 2014 on the western side of the four districts. Typhoid and viral hepatitis A cases illustrated minimal hotspot areas and the smoothed areas were spaced out, which could be due to the dispersing of cases in space. Dysentery was not mapped with KDE as there were only two cases. Geographic Information System (GIS) has been effectively used in various fields including healthcare. Its implementation in healthcare is an important step towards the growth of smart and focused interventions, bringing forth better health outcomes with a diminution in the cost of healthcare services (Hart et al. 2005).

Table 3 depicts the average nearest neighbour analysis of the FWBD cases from 2011 to 2014. The reported cases of typhoid, viral hepatitis A, and even dysentery did not show any clusters, whereas the null result appeared as there were too few records for analysis as it generally required at least two features. Even though this study had only a total of 17 confirmed cases of viral hepatitis A reported and no clusters were identified, the cases were significantly dispersed spatially. In an outbreak investigation of hepatitis A in children in an urban slum of Tamil Nadu, the cases were distributed with no particular clustering, which indicated that the outbreak might be due to a generalised source such as water contamination and not as a result of a point-source spread. The lack of spatial clustering helped to formulate the hypothesis that the outbreak could have been due to the contamination of water supply to the entire area (Sowmyanarayanan et al. 2008).

In this study, too few dysentery cases were reported and thus no clusters were detected. However, in China, the fluctuations of Shigella clusters found had caused food poisoning and dysentery (Tang et al. 2014). The incidence of dysentery in an urban area can be attributed to poor hygiene. Furthermore, such cases are influenced by meteorological factors such as a rise in temperature and relative humidity, which will increase the incidence of cases; these findings should be considered in relevant prevention and control programmes ( $\mathrm{Li}$ et al. 2015).

In 2011, only Kota Kinabalu and Papar illustrated food poisoning clusters. Between the year 2012 and 2014, Kota Kinabalu, Penampang, and Putatan had a clustering of food poisoning cases. This study found hotspot clusters that occurred in institutions such as schools, whereby school lunch programmes might potentially have bacterial growth in their food due to early preparation and handling. The use of GIS in epidemiological investigation and analysis of food production may assist in locating the sources or vehicles of infection. Contamination could be further linked to food production that took place in a direct spatial and temporal association. Further spread of infection caused by the primary source can be probably avoided by immediate measures (Kistemann et al. 2000).

Cholera showed several clustering of cases, such as in 2011 and 2014 in Kota Kinabalu. In the years of 2011 and 2013, Penampang and Papar districts were shown to have the nearest neighbour index of less than 1 for cholera, but the p-value was not significant and meant that the pattern did not appear to be significant. Further analysis with the Ripley $\mathrm{K}$ function exhibited the most significant distance clustering for food poisoning and cholera, which were up to $1.8 \mathrm{~km}$ and $3.3 \mathrm{~km}$, respectively. Ripley K function has slightly different results compared to the average nearest neighbour analysis as it considers second-order clusters and not just the measurement distance of the nearest neighbours. Typhoid cases in the year 2012 showed clustering at a very short distance, which was not observed in the average nearest neighbour analysis.

There were four food poisoning and cholera points, respectively, and one typhoid point at a 500-metre radius around the marketplace. Meanwhile, there were only two food poisoning points and one cholera and typhoid point, respectively, near a sewage plant. There were no cases in a 500-metre radius around the municipal landfill, while only one food poisoning point was found near a water treatment plant. Then, a proximity analysis was also done for rivers and coastlines, which displayed the most prominent findings. There were 37 points of food 
poisoning, 43 cholera points, 6 typhoid points, 2 viral hepatitis A points, and 1 dysentery point within 500 metres near a river and coastline (Table 4). Pathogen contamination is a major cause of stream impairments, making it a major health risk (Pandey et al. 2014). Persistent and heavy rainfall may affect the health in areas near rivers when flooding occurs, as it increases the risks of infectious diarrhoea in the affected areas (Ding et al. 2013). A close affiliation was found between the health condition and viral contamination of wastewater product effluents, and consequently, the surface water contamination (Prevost et al. 2015).

Nearest neighbour hierarchical clustering analysis was used with a pair of points by a chance of $0.50,10$ minimum points per cluster, and 1 standard deviation. There were no clusters identified for typhoid, viral hepatitis A, and dysentery, while the typhoid cases did not show spatial clustering. This finding conflicts with other study findings. For example, a typhoid study in Kelantan showed that typhoid usually occurred in clusters and each case usually occurred near other cases as the causative agent would be present in the surrounding area (Safian et al. 2008). Clusters of typhoid are also influenced by the environment, such as a change in the temperature, rainfall, and river level (Dewan et al. 2013).

Food poisoning had a total of 32 clusters; of those, 29 were first-order and 3 were second-order clusters (Figure 5). The findings in this study exhibited significant clustering of cases in food poisoning in which some clusters were also found in villages and squatter areas. Similar spatial studies were done before to demonstrate these areas to have a clustering of FWBD cases, which were associated with the shortage of safe drinking water and poor sanitation (Kazembe et al. 2009). Besides, adequate facilities and infrastructures, which include safe water access and sanitation, are needed to avoid pathogens that are causing diarrhoea (Zuckerman et al. 2007).

Cholera had seven clusters; of those, six were firstorder and one was a second-order cluster (Figure 6). Cholera could be observed in areas with higher population density and might be due to the increased density of refuse dumps and breakdown of sanitation, which led to a higher risk of cholera in a particular area (Kanungo et al. 2012). Meanwhile, isolated clusters of high cholera incidence may be attributed to poor hygiene practice in the community. Next, endemic cholera may occur when its reservoirs are readily available in coastal areas and the sea (Ali et al. 2006). Temporal seasons, which cause optimal taking in of nutrient and sunlight, are the best conditions for plankton growth (Abdul Rauf et al. 2011). Cholera distribution is influenced by the temperature, precipitation, elevation, distance to the coastline, and oceanic environmental factors, such as sea surface temperature, sea surface height, and ocean chlorophyll concentration. With this information, a forecast using GIS can offer great prospects as a forewarning method for cholera (Xu et al. 2015).

This study is not without its limitations; when using surveillance data, there is the possibility of underreporting of FWBD cases. Furthermore, this study did not include climate factors in the analysis.

TABLE 1. Patient characteristics of FWBDs from 2011 to 2014 in Kota Kinabalu, Penampang, Putatan, and Papar, Sabah

\begin{tabular}{lc}
\hline Characteristics & $\mathrm{n}(\%) \mathrm{N}=1997$ \\
\hline Age & $8(0.4)$ \\
Under 1 year old & $60(3.0)$ \\
1 to 4 years old & $208(10.4)$ \\
5 to 9 years old & $441(22.1)$ \\
10 to 14 years old & $431(21.6)$ \\
15 to 19 years old & $330(16.5)$ \\
20 to 24 years old & $146(7.3)$ \\
25 to 29 years old & $91(4.6)$ \\
30 to 34 years old & $74(3.7)$ \\
35 to 39 years old & $65(3.3)$ \\
40 to 44 years old & $58(2.9)$ \\
45 to 49 years old & $28(1.4)$ \\
50 to 54 years old & $23(1.2)$ \\
55 to 59 years old & $15(0.8)$ \\
60 to 64 years old & $19(1.0)$ \\
65 years and above &
\end{tabular}


Gender

Male

903 (45.2)

Female

$1094(54.8)$

Ethnic

Malay

$182(9.1)$

Chinese

154 (7.7)

Indian

$10(0.5)$

Peribumi Sabah

$1421(71.2)$

Peribumi Sarawak

31 (1.6)

Others

Non Malaysian

$148(7.4)$

Diagnosis

Food poisoning

$1787(89.4)$

Cholera

Typhoid

$29(1.5)$

Viral Hepatitis A

$17(0.9)$

Dysentery

$2(0.1)$

TABLE 2. Chi-square test between outbreak and sporadic cases of food and waterborne cases in the four districts of Sabah from 2011 to 2014

\begin{tabular}{|c|c|c|c|c|}
\hline Variables & $\begin{array}{c}\text { Outbreak } \\
\mathrm{N}=1701 \\
\mathrm{n}(\%)\end{array}$ & $\begin{array}{c}\text { Sporadic } \\
\mathrm{N}=296 \\
\mathrm{n}(\%)\end{array}$ & $\chi^{2}$ & p-value \\
\hline Gender & & & 0.820 & 0.365 \\
\hline Male & $762(84.4)$ & $141(15.6)$ & & \\
\hline Female & $939(85.8)$ & $155(14.2)$ & & \\
\hline District & & & 233.355 & $<0.01 *$ \\
\hline Kota Kinabalu & $1276(93.3)$ & $92(6.7)$ & & \\
\hline Penampang & $225(67.0)$ & $111(33.0)$ & & \\
\hline Putatan & $105(63.3)$ & $61(36.7)$ & & \\
\hline Papar & $95(74.8)$ & $32(25.2)$ & & \\
\hline Ethnicity & & & 16.204 & $<0.05^{*}$ \\
\hline Malay & $154(84.6)$ & $28(15.4)$ & & \\
\hline Chinese & $129(83.8)$ & $25(16.2)$ & & \\
\hline Indian & $9(90.0)$ & $1(10.0)$ & & \\
\hline Peribumi Sabah & $1227(86.3)$ & 194(13.7) & & \\
\hline Peribumi Sarawak & $29(93.5)$ & $2(6.5)$ & & \\
\hline Other Malaysian & $37(72.0)$ & $14(28.0)$ & & \\
\hline Non-Malaysian & $116(78.4)$ & $32(21.6)$ & & \\
\hline
\end{tabular}




\begin{tabular}{lcc} 
Age & & \\
Under 1 year old & $2(25.0)$ & $6(75.0)$ \\
1 to 4 & $33(55.0)$ & $27(45.0)$ \\
5 to 9 & $182(87.5)$ & $26(12.5)$ \\
10 to 14 & $416(94.3)$ & $25(5.7)$ \\
15 to 19 & $406(94.2)$ & $25(5.8)$ \\
20 to 24 & $287(87.0)$ & $43(13.0)$ \\
25 to 29 & $111(76.0)$ & $35(24.0)$ \\
30 to 34 & $64(70.3)$ & $27(29.7)$ \\
35 to 39 & $57(77.0)$ & $17(23.0)$ \\
40 to 44 & $55(84.6)$ & $10(15.4)$ \\
45 to 49 & $44(75.9)$ & $14(24.1)$ \\
50 to 54 & $20(71.4)$ & $8(28.6)$ \\
55 to 59 & $10(43.5)$ & $13(56.5)$ \\
60 to 65 & $8(53.3)$ & $7(46.7)$ \\
65 years and above & $6(31.6)$ & $13(68.4)$ \\
& & \\
\hline
\end{tabular}

*significant p-value of $<0.05$

TABLE 3. Average nearest neighbour analysis for FWBD cases from 2011 to 2014

\begin{tabular}{|c|c|c|c|c|c|}
\hline & & $\begin{array}{c}2011 \\
(\mathrm{NNI})\end{array}$ & $\begin{array}{c}2012 \\
(\mathrm{NNI})\end{array}$ & $\begin{array}{c}2013 \\
(\mathrm{NNI})\end{array}$ & $\begin{array}{c}2014 \\
(\mathrm{NNI})\end{array}$ \\
\hline \multirow[t]{4}{*}{ Kota Kinabalu } & Food Poisoning & $0.000^{\mathrm{a}}$ & $0.010 * \mathrm{a}$ & 0.117 * a & $0.000 * \mathrm{a}$ \\
\hline & Cholera & $0.609 * \mathrm{a}$ & $2.028 * \mathrm{~b}$ & $1.662 * b$ & $0.682 * \mathrm{a}$ \\
\hline & Typhoid & $184.387 * \mathrm{~b}$ & $131.547 * \mathrm{~b}$ & Null & $212.650 * \mathrm{~b}$ \\
\hline & Viral Hepatitis A & Null & $4.583 * \mathrm{~b}$ & $3.989 * \mathrm{~b}$ & $109.820 * \mathrm{~b}$ \\
\hline \multirow[t]{4}{*}{ Penampang } & Food Poisoning & $2.414^{* b}$ & $0.539 * \mathrm{a}$ & $0.417 * \mathrm{a}$ & $0.470 *$ a \\
\hline & Cholera & $0.834^{\mathrm{a}}$ & $2.007 * \mathrm{~b}$ & $2.324 * \mathrm{~b}$ & $1.927 * \mathrm{~b}$ \\
\hline & Typhoid & Null & Null & Null & Null \\
\hline & Viral Hepatitis A & Null & Null & Null & Null \\
\hline \multirow[t]{4}{*}{ Putatan } & Food Poisoning & Null & $0.439 * a$ & $0.904 * \mathrm{a}$ & $0.546^{* a}$ \\
\hline & Cholera & Null & $1.041^{\mathrm{b}}$ & $83.249 * b$ & $2.899 * b$ \\
\hline & Typhoid & Null & $2.100 * \mathrm{~b}$ & Null & $87.149 * \mathrm{~b}$ \\
\hline & Viral Hepatitis A & Null & Null & Null & Null \\
\hline \multirow[t]{4}{*}{ Papar } & Food Poisoning & $0.375^{* a}$ & $1.695 * \mathrm{~b}$ & $1.490 * \mathrm{~b}$ & $1.371 * \mathrm{~b}$ \\
\hline & Cholera & Null & $1.937 * \mathrm{~b}$ & $0.918^{\mathrm{a}}$ & Null \\
\hline & Typhoid & $2.095 * \mathrm{~b}$ & $2.381 * \mathrm{~b}$ & Null & Null \\
\hline & Viral Hepatitis A & $239.849 * b$ & $89.547 * \mathrm{~b}$ & Null & Null \\
\hline
\end{tabular}

Nearest Neighbour Index (NNI): if the ratio is less than 1, it is clustered; if the ratio is larger than 1, it is dispersed.

${ }^{*} \mathrm{p}$-value $<0.01$, ${ }^{\mathrm{a}}$ clustered, ${ }^{\mathrm{b}}$ dispersed 
TABLE 4. Proximity analysis in the range of 500 metres near environmental features

\begin{tabular}{|c|c|c|c|c|c|}
\hline Diagnosis & Market & Sewage plant & Municipal landfill & Water treatment plant & $\begin{array}{l}\text { River and } \\
\text { coastline }\end{array}$ \\
\hline Food poisoning & 4 & 2 & 0 & 1 & 37 \\
\hline Cholera & 4 & 1 & 0 & 0 & 43 \\
\hline Typhoid & 1 & 1 & 0 & 0 & 6 \\
\hline Viral Hepatitis A & 0 & 0 & 0 & 0 & 2 \\
\hline Dysentery & 0 & 0 & 0 & 0 & 1 \\
\hline
\end{tabular}

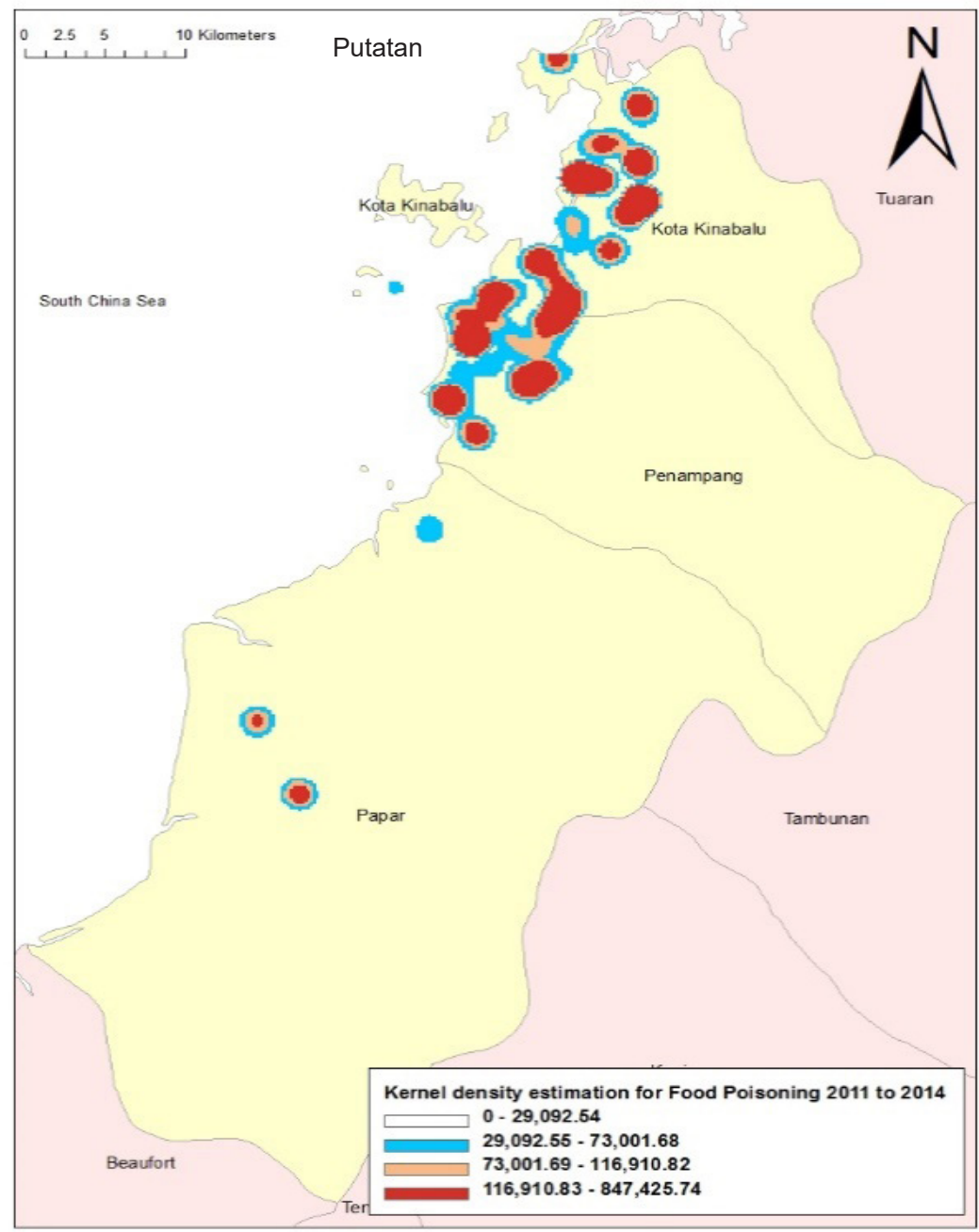

FIGURE 1. Kernel density estimation of reported food poisoning in the four districts of Sabah from 2011 to 2014 


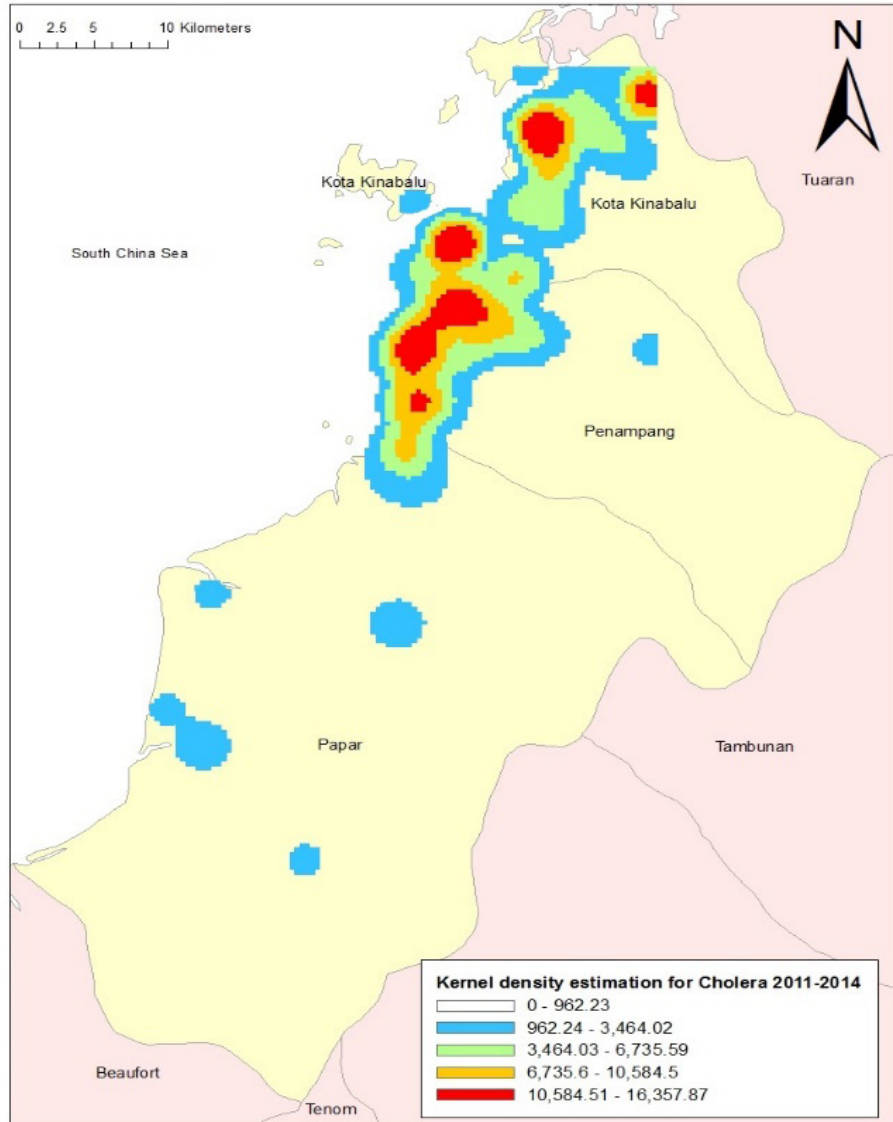

FIGURE 2. Kernel density estimation of reported cholera in the four districts of Sabah from 2011 to 2014

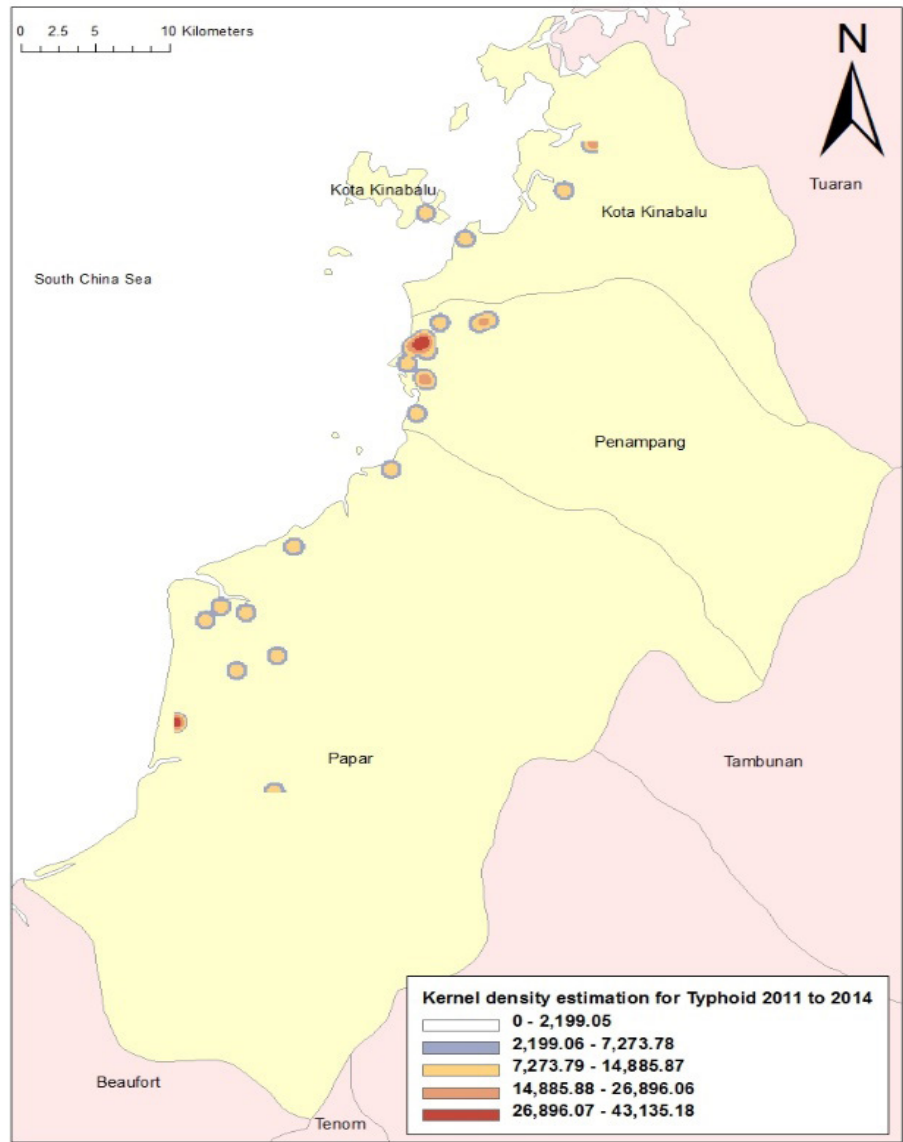

FIGURE 3. Kernel density estimation of reported typhoid in the four districts of Sabah from 2011 to 2014 


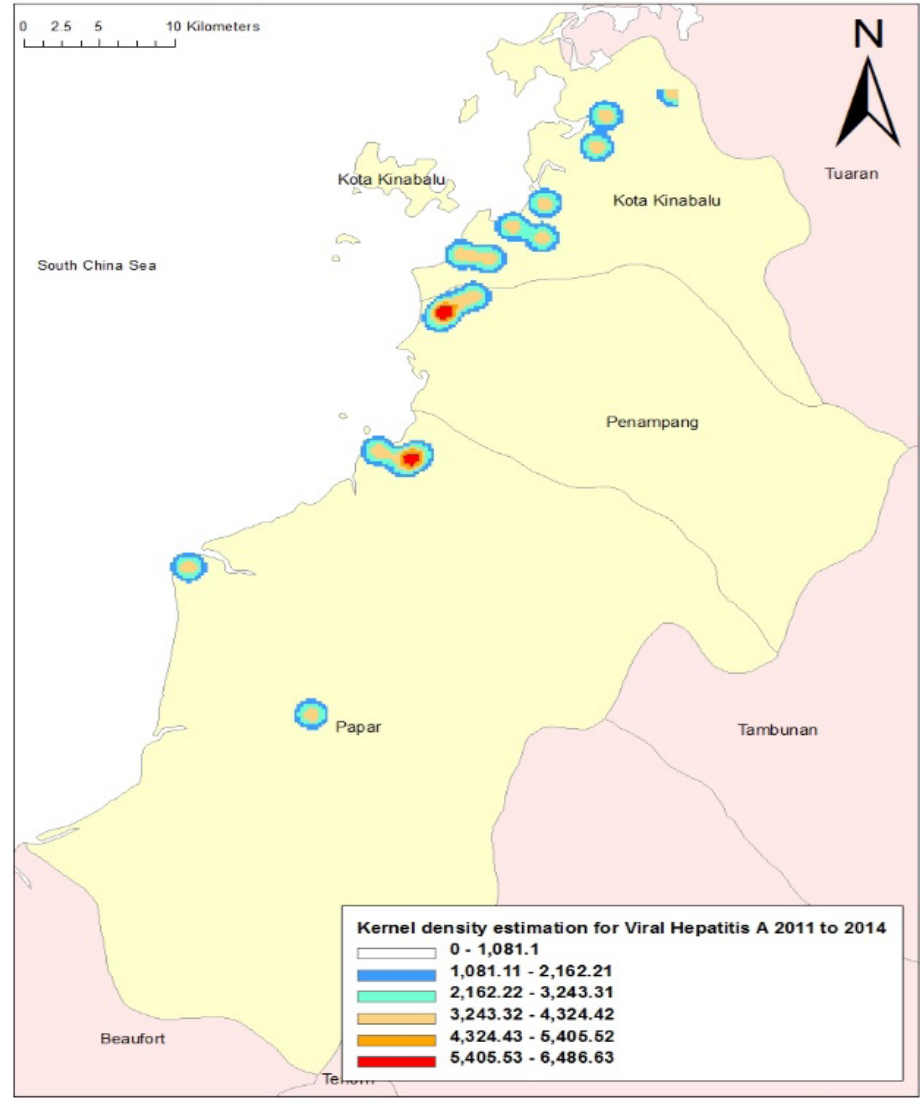

FIGURE 4. Kernel density estimation of reported viral hepatitis A in the four districts of Sabah from 2011 to 2014

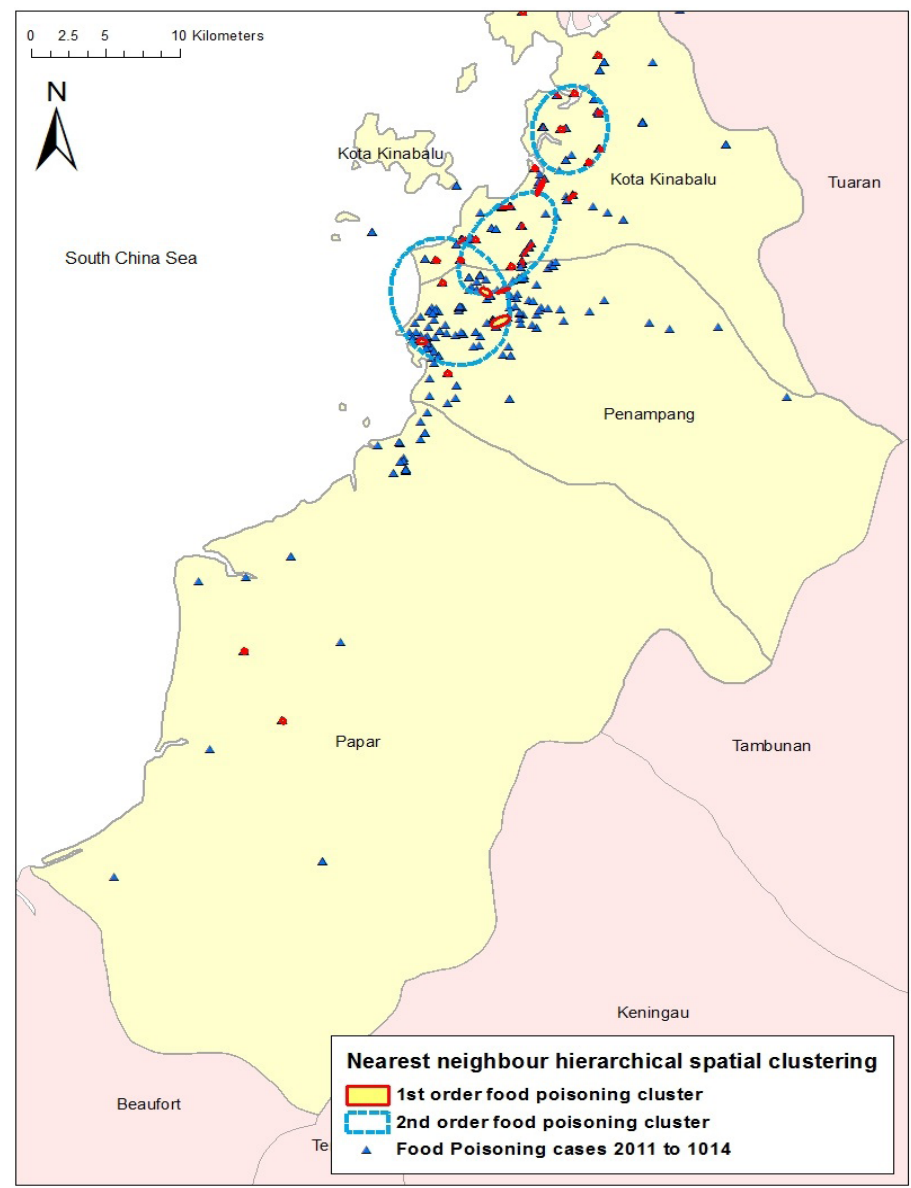

FIGURE 5. Nearest neighbour hierarchical spatial clustering analysis of food poisoning cases in the four districts of Sabah from 2011 to 2014 


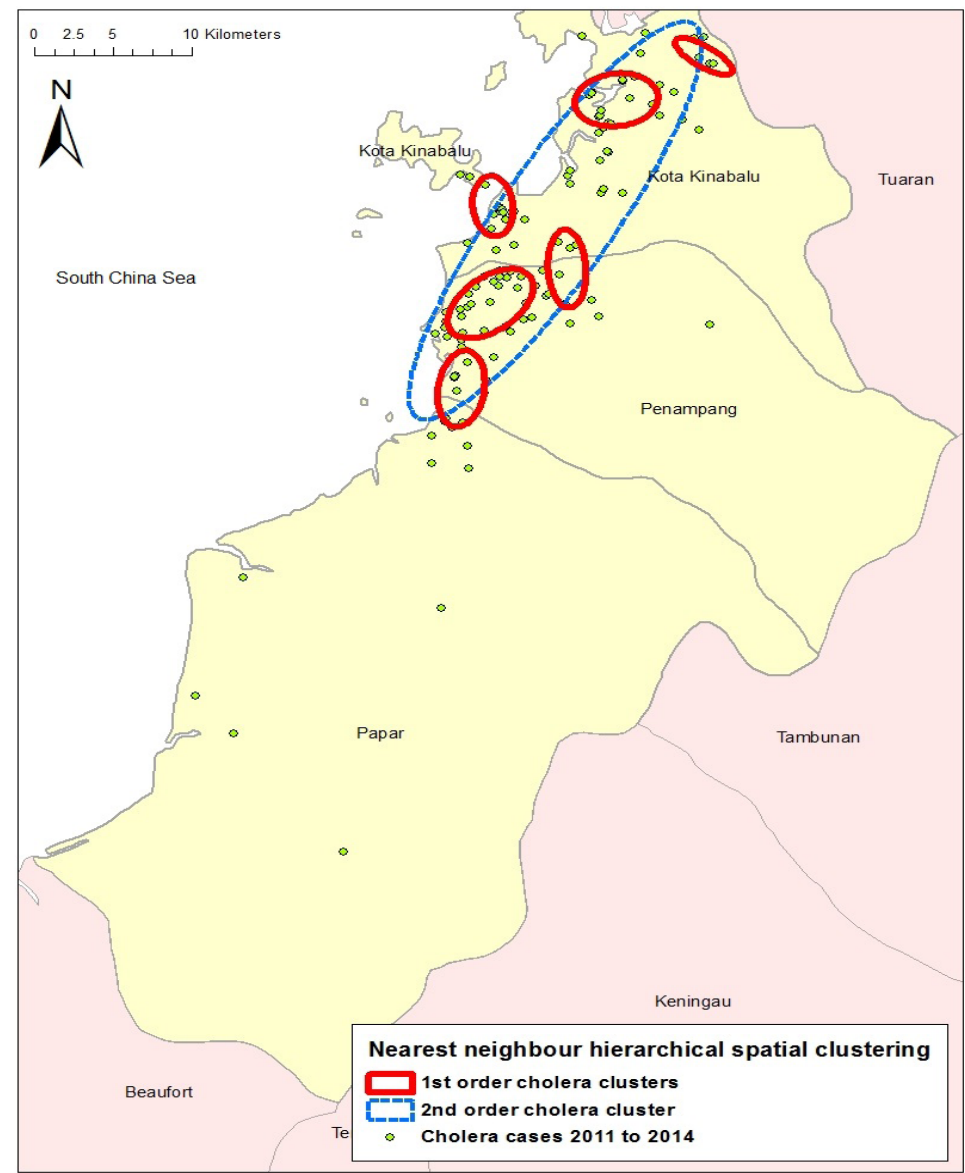

FIGURE 6. Nearest neighbour hierarchical spatial clustering analysis of cholera cases in the four districts of Sabah from 2011 to 2014

\section{CONCLUSION}

From these findings, one could conclude that for these particular areas, food poisoning and cholera had significant spatial clustering and patterns. However, other food water-borne diseases did not occur in clusters. This could mean that the real cases and burden were either not captured and there is under-reporting, or these were the real dispersion of cases, which was brought about by an efficient mechanism of spread from a common source.

\section{ACKNOWLEDGEMENTS}

We would like to thank the Director-General of Health Malaysia for his permission to publish this article. The authors would also like to express our gratitude to the Sabah State Health Department, particularly Kota Kinabalu Area Health Office, Penampang Area Health Office, Papar Area Health Office and Putatan District Health Office.

\section{REFERENCES}

Abdul Rauf Abdul Rasam \& Abdul Malek Mohd Noor 2012. Contribution of GIS and remote sensing technologies for managing foodborne diseases in Malaysia. IEEE Control and System Graduate Research Colloqiuium. pp. 258-261.

Abdul Rauf Abdul Rasam, Abdul Malek Mohd Noor, Norazah Ahmad \& Rosmadi Ghazali. 2011. MyGeoHealth: GISbased cholera transmission risk system in Sabah, Malaysia. IEEE 7th International Colloquium on Signal Processing and its Applications. pp. 474-479.

Alhoot, M.A., Tong, W.T., Low, W.L. \& Sekaran, S.D. 2016. Climate change and health: The Malaysia scenario. In Climate Change and Human Health Scenario in South and Southeast Asia. Advances in Asian Human-Environmental Research, edited by Akhtar R. Springer, Cham. pp. 243-268.

Ali, M., Goovaerts, P., Nazia, N., Haq, M.Z., Yunus, M. \& Emch, M. 2006. Application of poisson kriging to the mapping of cholera and dysentery incidence in an endemic area of Bangladesh. International Journal of Health Geographics 5(1): 45 . 
Anselin, L., Cohen, J., Cook, D., Gorr, W. \& Tita, G. 2000. Spatial analyses of crime. Criminal Justice 4: 213-262.

Asao, T., Kumeda, Y., Kawai, T., Shibata, T., Oda, H., Haruki, K., Nakazawa, H. \& Kozaki, S. 2003. An extensive outbreak of staphylococcal food poisoning due to low-fat milk in Japan: Estimation of enterotoxin A in the incriminated milk and powdered skim milk. Epidemiology and Infection 130(1): 33-40.

Carrel, M., Emch, M., Streatfield, P.K. \& Yunus, M. 2009. Spatio-temporal clustering of cholera: The impact of flood control in matlab, Bangladesh, 1983-2003. Health \& Place 15(3): 741-752.

Dewan, A.M., Corner, R., Hashizume, M. \& Ongee, E.T. 2013. Typhoid fever and its association with environmental factors in the Dhaka metropolitan area of Bangladesh: A spatial and time-series approach. PLoS Neglected Tropical Diseases 7(1): 12-15.

Ding, G., Zhang, Y., Gao, L., Ma, W., Li, X., Liu, J., Liu, Q. \& Jiang, B. 2013. Quantitative analysis of burden of infectious diarrhea associated with floods in Northwest of Anhui province, China: A mixed method evaluation. PloS ONE 8(6): e65112.

DOSM. 2020. Department of Statistics Malaysia Official Portal. https://www.dosm.gov.my/v1/index.php?r=column/ cone\&menu_id=dTZ0K2o4YXgrSDRtaEJyVmZ1R2h5 dz09.

Esri. 2013. ArcGIS Help 10.1 - Resource Center. http://resources. arcgis.com/en/help/main/10.1/index.html\#/Welcome_to_the ArcGIS_Help_Library/00qn0000001p000000/.

Gurpreet, K., Tee, G.H., Amal, N.M., Paramesarvathy, R. \& Karuthan, C. 2011. Incidence and determinants of acute diarrhoea in Malaysia: A population-based study. Journal of Health, Population and Nutrition 29(2): 103-112.

Hart, A., McCulloch, B., Harper, C., Gardiner, N., Rutherford, S., Baker, P. \& O'Sullivan, D. 2005. Report on GIS and Public Health Spatial Applications. Brisbane: Queensland Health.

Kanungo, S., Sur, D., Ali, M., You, Y.A., Pal, D., Manna, B., Niyogi, S.K., Sarkar, B., Bhattacharya, S.K., Clemens, J.D. \& Nair, G.B. 2012. Clinical, epidemiological and spatial characteristics of Vibrio parahaemolyticus diarrhea and cholera in the urban slums of Kolkata, India. BMC Public Health 12(1): 830.

Kazembe, L.N., Muula, A.S. \& Simoonga, C. 2009. Joint spatial modelling of common morbidities of childhood fever and diarrhoea in Malawi. Health \& Place 15(1): 165-172.

Kistemann, T., Dangendorf, F., Krizek, L., Sahl, H.G., Engelhart, S. \& Exner, M. 2000. GIS-supported investigation of a nosocomial Salmonella outbreak. International Journal of Hygiene and Environmental Health 203(2): 117-126.

Li, Z.J., Zhang, X.J., Hou, X.X., Xu, S., Zhang, J.S., Song, H.B. \& Lin, H.L. 2015. Nonlinear and threshold of the association between meteorological factors and bacillary dysentery in Beijing, China. Epidemiology and Infection 143(16): 3510-3519.

Ministry of Health. 2006. Garis Panduan Pengurusan Wabak Kolera. 2nd ed. Putrajaya: Ministry of Health.

Nazarudin, S., Shah, S.A., Idrus, S. \& Hamzah, W.M. 2008. Cluster analysis of typhoid cases in Kota Bharu, Kelantan, Malaysia. Medical Journal of Indonesia 17(3): 175-182.

Newell, D.G., Koopmans, M., Verhoef, L., Duizer, E., Aidara-
Kane, A., Sprong, H., Opsteegh, M., Langelar, M., Threfall, J., Scheutz, F., Giessen, J.V.D. \& Kruse, H. 2010. Foodborne diseases - the challenges of 20 years ago still persist while new ones continue to emerge. International Journal of Food Microbiology 139(2010): S3-S15.

Pandey, P.K., Kass, P.H., Soupir, M.L., Biswas, S. \& Singh, V.P. 2014. Contamination of water resources by pathogenic bacteria. AMB Express 4(1): 51 .

Pardhan-Ali, A., Berke, O., Wilson, J., Edge, V.L., Furgal, C., Reid-Smith, R., Santos, M. \& McEwen, S.A. 2012. A spatial and temporal analysis of notifiable gastrointestinal illness in the Northwest territories, Canada, 1991-2008. International Journal of Health Geographics 11(1): 17.

Prevost, B., Lucas, F.S., Goncalves, A., Richard, F., Moulin, L. \& Wurtzer, S. 2015. Large scale survey of enteric viruses in river and waste water underlines the health status of the local population. Environment International 79: 42-50.

Soon, J.M., Singh, H. \& Baines, R. 2011. Foodborne diseases in Malaysia: A review. Food Control 22(6): 823-830.

Sowmyanarayanan, T.V., Mukhopadhya, A., Gladstone, B.P., Sarkar, R. \& Kang, G. 2008. Investigation of a hepatitis A outbreak in children in an urban slum in Vellore, Tamil Nadu, using Geographic Information Systems. Indian Journal of Medical Research 128(1): 32-37.

Tam, C.C. 2008. Fortune and foreigners: Toward an epidemiology of food (borne illness). Epidemiology 19(2): 291-293.

Tang, F., Cheng, Y., Bao, C., Hu, J., Liu, W., Liang, Q., Wu, Y., Norris, J., Peng, Z., Yu, R., Shen, H. \& Chen, F. 2014. Spatiotemporal trends and risk factors for Shigella from 2001 to 2011 in Jiangsu Province, People's Republic of China. PloS ONE 9(1): e83487.

Xu, M., Cao, C.X., Wang, D.C., Kan, B., Xu, Y.F., Ni, X.L. \& Zhu, Z.C. 2016. Environmental factor analysis of cholera in China using remote sensing and geographical information systems. Epidemiology and Infection 144(5): 940-951.

Zuckerman, J.N., Rombo, L. \& Fisch, A. 2007. The true burden and risk of cholera: Implications for prevention and control The Lancet Infectious Diseases 7(8): 521-530.

Syed Sharizman Syed Abdul Rahim*

Department of Community and Family Medicine

Faculty of Medicine and Health Sciences

Universiti Malaysia Sabah

88400 Kota Kinabalu, Sabah

Malaysia

Shamsul Azhar Shah, Mohd Rohaizat Hassan \& Nazarudin Safian Department of Community Health

Faculty of Medicine

Universiti Kebangsaan Malaysia

56000 Bandar Tun Razak, Cheras

Kuala Lumpur, Wilayah Persekutuan

Malaysia

Shaharudin Idrus

Institute for Environmental and Development

Universiti Kebangsaan Malaysia

43600 UKM Bangi, Selangor Darul Ehsan

Malaysia 
Zahir Izuan Azhar

Department of Population Health and Preventive Medicine

Faculty of Medicine

Universiti Teknologi MARA (UiTM)

47000 Sungai Buloh, Selangor Darul Ehsan

Malaysia
*Corresponding author; email: syedsharizman@gmail.com

Received: 15 February 2019

Accepted: 6 March 2020 